\title{
Macrophage-Stimulating Protein Receptor
}

National Cancer Institute

\section{Source}

National Cancer Institute. Macrophage-Stimulating Protein Receptor. NCI Thesaurus.

Code C28526.

Macrophage-stimulating protein receptor (1400 aa, 152 kDa) is encoded by the human MST 1R gene. This protein is involved in lig and binding, tyrosine phosphorylation and signal transduction. 